Man and Nature

L'homme et la nature

\title{
'To Keep Them in Proper Subjection': Jeffrey Amherst and the Indians
}

\section{David R. Farrell}

Volume 4, 1985

URI : https://id.erudit.org/iderudit/1011843ar

DOI : https://doi.org/10.7202/1011843ar

Aller au sommaire du numéro

Éditeur(s)

Canadian Society for Eighteenth-Century Studies / Société canadienne d'étude du dix-huitième siècle

ISSN

0824-3298 (imprimé)

1927-8810 (numérique)

Découvrir la revue

Citer cet article

Farrell, D. R. (1985). 'To Keep Them in Proper Subjection': Jeffrey Amherst and the Indians. Man and Nature / L'homme et la nature, 4, 155-169.

https://doi.org/10.7202/1011843ar

Copyright (C Canadian Society for Eighteenth-Century Studies / Sociéte canadienne d'étude du dix-huitième siècle, 1985
Ce document est protégé par la loi sur le droit d'auteur. L'utilisation des services d'Érudit (y compris la reproduction) est assujettie à sa politique d'utilisation que vous pouvez consulter en ligne.

https://apropos.erudit.org/fr/usagers/politique-dutilisation/ 


\section{0. 'To Keep Them in Proper Subjection': Jeffrey Amherst and the Indians}

The Indians,' wrote commanding general Jeffrey Amherst in November 1760 , 'would never be of any great value, yet against us they may be of great disservice..' ${ }^{1}$ Informed of the unexpected and, as he steadfastly assumed, the unwarranted war initiated by the Cherokee in 1759, Amherst condemned 'that perfidious race of savages.' There was only one alternative: it remains now for us to chastise their insolence and reduce them so low that they may never be so able to be guilty of the like again'. ${ }^{2}$ When the Cherokee finally did agree to negotiate, the General was convinced they did so from 'no other motive than their certainty of our present superiority. ${ }^{3}$ Only through the demonstration of sufficient force could the tribes be kept in proper subjection.

Amherst was careful to remind colonial officials that the Indians will always be our best neighbors when they see we are in a state to defend ourselves should they be inclined to mischief. ${ }^{4}$ Writing to Detroit commandant Major Henry Gladwin in May 1763, he once again reiterated that it was 'certainly best to be always on our guard against any attempt of the Indians ... they never can hurt us unless we are weak enough to put ourselves in their power.' But Amherst was convinced that they would 'show us no mercy if they thought they could escape with impunity. ${ }^{5}$ Gladwin needed no such reminder. Unknown to Amherst, three weeks earlier the Indians had indeed struck without mercy. Nine British forts were destroyed, hundreds of troops and civilians were killed or cap- 
tured, and Gladwin's command as the last British stronghold west of Niagara was surrounded and under siege.

Neither historians nor his contemporaries have been kind in assessing Amherst's Indian policy, and it is indeed difficult to find much insight in his approach. ${ }^{6}$ It was, after all, his program of defence which brought so many relocated soldiers into the Indian country. It was also his decision to curtail the issuance of supplies and presents which so alienated Indian hunter-warriors. At best, Amherst's actions may be discounted as inept and insensitive; at worst, they could be considered devious and crude efforts to coerce the Indians into total subservience.

Even during the war years Amherst had considered the Indians to be most uncomfortable allies. Instructed by Pitt as early as 1758 to 'cultivate' the tribes, this always remained 'an alliance foreign to Amherst's nature and preference'. ${ }^{7}$ Perhaps conditioned by years of quartermaster service, he could never accept the vast expenditures involved in maintaining Indian allegiances. Despite continual pleas by Indian Superintendent Sir William Johnson to court their favor, Amherst invariably sent warriors back to their villages. He considered them the most idle and worthless asset ${ }^{\prime}$ and even their work as scouts was discounted. At best he felt they were mere opportunists who wished to gain praise and gifts from all concerned: thus it is their business to give intelligence on both sides'. ${ }^{9}$

Above all, Amherst could never reconcile himself to 'the savages on account of their habits and methods of warfare' ${ }^{10} \mathrm{He}$ abhorred their undisciplined and highly individualistic style of fighting and was shocked at the cruelties with which they treated their foes. When he had refused to share either booty or prisoners taken at La Galette in 1759, he was horrified as 'the Indians scratched up dead bodies and scalped them as if it had been the greatest feast to them'. ${ }^{11}$ In a vain effort to understand the tribes better, he happened to visit an Oneida village in the midst of a victory celebration. During an ensuing brawl, Amherst watched as several Indians were killed and others in a drunken frenzy hacked a horse to death. His reaction was predictable. 'They are devils when drunk; when sober quiet enough. ${ }^{12}$

It was clear to Amherst that only stern discipline and severe restraint could keep his allies in line. After an Indian was found guilty of murder (by the formality of an English court-martial), Amherst refused all requests of his fellow tribesmen, allies in the British camp, for mercy: 'I would serve every villain that deserved death as much as he did in the same way. I believe it is the best way of treating Indians'. ${ }^{13}$ But at least he was consistent. He considered British traders self-interested profiteers who must be strictly regulated; Canadien residents in the interior, 
already half-savaged by implication, persisted in spreading 'falsehoods' among the tribes and could not be trusted; English deserters were flogged or executed; two soldiers, whose 'cruelties and barbarities' committed against their countrymen while fighting for the Indians 'were shocking to relate', ${ }^{14}$ were sentenced to death. So too was a soldier from the 44th Regiment who was accused of robbery and a Frenchman who was found guilty of murder. Although beyond his jurisdiction, the colonial legislatures which balked at voting men or supplies 'for the King's service' were equally condemned. Amherst proposed that the four most irksome (Rhode Island, Connecticut, Pennsylvania and Maryland), in particular, should revert to royal status so that a greater measure of authority and discipline could be established over the recalcitrant colonials.

In retrospect, Jeffrey Amherst seemed to be a 'remarkable' choice as commander-in-chief of British North American forces. ${ }^{15}$ In over 20 years of military service this former guardsman and aide-de-camp had never commanded so much as a regiment, let alone an army in the midst of a major offensive. Yet in 1758 he was selected by William Pitt to head the assault on Louisbourg despite being junior to a number of more experienced combat officers. Denied any role in planning the operation, Amherst had in fact arrived in North America barely in time to join his invasion force which was already at sea. At Louisbourg, Amherst demonstrated considerable ability in coordinating the joint land-sea venture (an enterprise highly favored by Pitt) which culminated in a successful if unspectacular British victory. Several months later he was rewarded with appointment as supreme commander in North America. ${ }^{16}$

Within two years the British had achieved total victory in Canada. While Amherst replaced the disgraced Abercrombie on the Lake Champlain front for the campaign of 1759, Major General James Wolfe was given virtual autonomous command of the assault on Quebec. This flamboyant and somewhat impetuous commander, who had an impressive career as regimental commander, was in sharp contrast to Amherst whose reputation was made as a deliberate and thorough administrator who showed an 'infinite capacity' for the detail of staff work. ${ }^{17}$ The subsequent campaign of each man reflected their differences in temperament. By year's end Wolfe had gained his objective in a dramatic, and fatal, eleventh-hour assault. Meanwhile, after a painstakingly deliberate movement against the French forts on Lake George, Amherst was entering winter quarters preparatory to yet another season's fighting.

Amherst's plan for 1760 was designed to eliminate systematically all French resistance along the St. Lawrence. Despite rumours of French counter-attacks, he recognized that the British control of Quebec City 
was secure; he thus proposed to trap the remaining French forces by converging on Montreal from three directions. Leaving one column to move up the Lake Champlain route and a second to move along the St. Lawrence from Quebec City, Amherst took personal command of the force driving toward Lake Ontario to take Montreal from the west. Although this cumbersome and somewhat precarious division of forces has been criticized as needlessly delaying the apparently inevitable defeat of the French army, Amherst was determined to prevent any possible French retreat to the sanctuary of their forts and Indian allies in the Great Lakes country or in Illinois. He was particularly pleased that the three widely separated British columns, with virtually no contact between them, all converged on Montreal within 48 hours of each other. There they forced the capitulation of Canada's Governor Vaudreuil on September 8.

Once the defeat of French arms was assured, Amherst moved to consolidate British control. Military expeditions were sent to occupy the western French forts and to open diplomatic and trade connections with France's Indian allies. In broad outline, the program for continental defence which he initiated reflected a wide consensus of current military thought in North America and London. Indian Superintendent Johnson, General Thomas Gage (Amherst's eventual successor as commander-inchief), and both the Pitt and Bute ministries all agreed that until the war was concluded in Europe every military theatre was considered at risk. It was thus to be Amherst's responsibility to provide for the protection of Canada and the West (against internal or external threat) even while assisting planned expeditions against the French West Indies, Spanish Cuba, and French-held Louisiana.

After the surrender of Canada, even Amherst admitted that the French were unlikely to 'dare to attempt anything offensively themselves' in North America. He was equally certain, however, that they 'will no doubt be ready enough to set the Indians to work in alarming our frontiers $^{\prime 18}$ from as yet unconquered outposts in Louisiana and Illinois. With his regular forces fully committed to the defence of the continent and the offensives in the Carribbean, he was constantly frustrated by the reluctance of colonial legislatures to supply additional manpower. Amherst was strapped.

Not a man could be spared 'with any degree of prudence' 19 from his already over-extended defences. As an example, he pointed to the first battalion of the Royal Americans (which in May 1763 would be decimated by Indian assault). After 1760, it alone was responsible for an 'immense length of communication' extending from Philadelphia to Mackinack, 
through country of which a greater part is inhabited by Indians who always have a plot in embryo, and nothing but fear of us can hinder these savages from attempting to execute their designs or keep them in any degree of subjugation. ${ }^{20}$

As long as England and France remained at war, Amherst was determined to solidify his defences. New fortifications were established at strategic sites throughout the interior, existing French forts were occupied and strengthened, while supplies of arms, ammunition and liquor for potential Indian foes were strictly curtailed.

Being neither aware of nor interested in Amherst's strategic concerns, the Indians saw only one reason for Britain's steadily mounting military preparations. Since the French were no longer a threat in America, the tribes could only assume that the British were now planning a war of annihilation against them. By assuming the Indians to be inherently warlike and hostile, Amherst was creating the very climate of animosity and tension which his military preparations were intended to prevent.

Both the defence and the future trade of the wilderness interior depended upon control of essential water routes. Beginning in Pennsylvania, a series of strongpoints guaranteed access west to Fort Pitt and the Ohio River; in New York a similar network of fortifications protected communications between the Mohawk Valley and Oswego on Lake Ontario. With these two basic routes secured, Amherst was assured of a reliable flow of supplies and reinforcements from the East. ${ }^{21}$

The next step was to establish an interdependent and mutually supporting defence system in the interior. The larger French forts at Pittsburgh, Niagara, Detroit and Mackinack were occupied, as were the smaller outposts which protected their hinterland approaches. Whenever necessary, new forts were built as well. One such project was begun at Sandusky Bay despite vociferous objections by the resident Huron, who were neither informed nor consulted beforehand. Strategically situated to protect communications along the southern coast of Lake Erie and to anchor the major overland trail connecting Detroit with Pittsburgh, Sandusky was considered an essential link for the completion of Amherst's defensive perimeter. Consequently, the Commander-in-Chief insisted that 'I must and will therefore, say what they [the Huron] will, have one at that place.'22

Potentially the weakest link in Amherst's western defences was the Niagara portage. This was the bottleneck through which the bulk of the military stores, trade goods, and fur exports flowed to and from the western forts. In 1761 a consortium of military officers interested in land speculation and merchants involved in the western fur trade requested a 
grant of 10,000 acres along the Niagara frontier. This project, whose 'advantages' were not only obvious but 'deserving encouragement', was 'cheerfully' transmitted by Amherst to London. Meanwhile, he advised the claimants to start settling families and livestock on the as yet unauthorized grant. ${ }^{23}$ The Niagara settlement, planned ostensibly as a community for English farmers who would raise provisions and help defend the portage route, aroused considerable protest. Dutch merchants at Albany feared it was only a poorly camouflaged attempt to monopolise the trans-shipment of merchandise and furs around the Falls. Even more alarmed were the resident Seneca, who denied that the British had any right to allocate and settle their lands without consent. Concerned by the Indians' reaction, Indian Superintendent Johnson urged that Amherst revoke the grant. He flatly refused.

Amherst finally had gone too far. In January 1763 , he was reminded by Secretary of State Egremont of the King's repeated promises that 'strict justice' be accorded the Indians 'by affording them His Royal protection from any encroachment on the lands they have reserved for themselves.'24 Continuation of this program was necessary while the Ministry hammered out the final format of what would become the Royal Proclamation of 1763, issued that October. The land grant at Niagara was formally annulled by London and only a small garrison remained to guard the portage.

Britain's first line of defence in the West continued to be centred on the major forts and their garrisons. Even Amherst realized, however, that physical coercion must be balanced by a 'steady, uniform and friendly conduct and behavior toward the Indians. ${ }^{25}$ Particularly important, as Sir William Johnson pointed out, was the attitude of the military officers who came in contact with the Indians. According to Johnson, it 'will be in great measure, if not entirely in the power of the commanding officers of the several forts and posts' to keep or lose the affection of the tribes. ${ }^{26}$ Johnson also reminded Amherst that a free, open and carefully regulated trade (he accepted a 50\% mark-up at western posts as a fair profit) was mandatory if good relations were to be maintained. Also, a few 'ministers and schoolmasters' sent among the Indians would 'tend greatly to the civilizing of even the worst of them, after which they could be the easier managed'.

On these points Amherst was in full agreement. Although he was irritated at the greed of individual traders 'whose sole views are to monopolise the whole of the profits to themselves'27, Amherst clearly appreciated the political implications of the fur trade. There was 'no doubt but it always lyes [sic] in our power, by totally prohibiting any goods to be taken to the Indians, to reduce them to our terms and that by treating 
them as they deserve they will behave as they ought to do.'28 Realistically, Amherst also knew that once Canada capitulated it was impossible that the French can much longer supply their wants, and whatever power does that must have them in subjection'.

Early reports sent to Amherst from the newly-occupied interior posts indicated that the western nations were 'well disposed, 'which as it is for their interest, I am willing to believe they will remain' and 'our intercourse must therefore be safe'. To 'make it still more so', he proposed 'not only to garrison these several posts properly but to appoint a person of knowledge and probity to be governor of the Detroit,' 29 which he considered to be the strategic and economic focus of the Lakes country. Amherst also wanted a rapid development of trade with the tribes who, 'so long as they behave well must not be imposed upon but receive a just equivalent for their furs. ${ }^{30}$ Indeed, even before sending an expedition from Montreal to occupy the West in late 1760, Amherst already had issued a circular letter to the colonial governors to 'invite the traders and adventurers of the provinces ... to transport themselves hither' where 'they may depend upon finding good markets and every encouragement they can reasonably wish or desire. ${ }^{\prime 31}$

An arrangement to guarantee a safe and reliable relationship with the Indians did not, however, imply granting charity. Once trade was fully established 'they will be able to supply themselves' from the traders: 'I do not see why the Crown should be put to that expense' of issuing arms, ammunition or other necessities; 'when they find they can get it on asking for it they will grow remiss in their hunting, which should industriously be avoided.' 32 Moreover, the necessity for Indian hunter-warriors to trap furs for trade would keep them from more dangerous activities: 'as long as their minds are on business they will not have leisure to hatch mischief.'

Despite his refusal to sanction large-scale issuance of presents to the Indians, Amherst was not totally blind to the principles of successful wilderness diplomacy. Occasional distribution of a few presents was acceptable, for 'service must be rewarded.' In particular he recommended allocating 50 silver medals to chiefs whose bravery and diligence had been proven during the war, in the hope that this would have 'a good effect' on England's more recalcitrant allies. ${ }^{33}$ Besides, Amherst reasoned, 'the expense is not great. ${ }^{34}$ However, 'as to purchasing their good behaviour,' this 'I do not understand.' On this point the General was adamant: 'when men of what race soever behave ill they must be punished, but not bribed.'

Not only were presents expensive, but Amherst felt they were also ineffective. Prior to the collapse of French military power, he noted that 
'the French had been at incredible expense for presents in maintaining these Indians in their interest notwithstanding of which, so soon as they saw the [British] army approach they forsook their benefactors and made offers of service to me. ${ }^{\prime 35}$ Aware of 'how little they were to be trusted,' Amherst promptly declined such alliances, 'desiring them only to remain neutral.' Nor was there any reason to anticipate that presents alone would be sufficient to maintain the Indians' allegiances.

Whenever these barbarians see our superiority they will soon forget these benefictions (sic) and desert their [previous] benefactors with a view to ward off punishment they so much merit at our hands....for without such [threats] there can be no prospect of a solid and lasting peace. ${ }^{36}$

The tribes clearly understood that 'I had the power in my hand and would make use of it to retaliate their hostilities and root them out entirely' if they strayed. Power, not presents, would determine Amherst's Indian diplomacy.

Militarily sound, Amherst's reasoning was politically dangerous. At Detroit, Captain Donald Campbell warned that if the Indians knew of the General's sentiments about keeping them short of powder if would be impossible to keep them in temper. ${ }^{\prime 37}$ The Detroit commandant was so concerned that he even refused to inform his Canadien interpreters of the embargoes placed on the sale of arms, ammunition and liquor. Nor could a frustrated Sir William Johnson, dependent on Amherst for funding the Indian Department, circumvent these cutbacks. But he too warned the Commander-in-Chief that such an approach was unwise. As the Indians 'have been used heretofore to receive presents in great abundance,' Johnson suggested that it might not be 'convenient to break off that expense all at once until everything be entirely settled throughout the country. ${ }^{\prime 38}$

A liberal program of issuing presents would solve several of Johnson's negotiating problems. Bountiful gifts could help smooth Indian irritations over land encroachments, trade abuses, and Britain's steadily growing military presence. If the tribes could be attracted to the major forts by offering presents, they would also bring their trade and thereby undercut the influence of the illegal traders residing in their villages. Centralizing the Indian trade at the larger forts should lessen the incidence of trade abuses, such as fraudulent weights and measures or reliance on the pervasive rum barrel to cheat the Indians of their furs. A closer supervision of trading activity also might prevent the warriors from secretly stockpiling large quantities of arms and ammunition preparatory to launching a full-scale war. If all else failed, Indian Department officials meeting in 
council could always work to arouse traditional inter-tribal enmities and turn the Indians' hostility against each other: a tactic which would prevent them from forming any type of pan-Indian confederacy to oppose the British. ${ }^{39}$

Surprisingly enough, given his rather jaundiced view of the Indians, Amherst disagreed with these opportunistic tactics. He continued to insist that further issuance of presents was expensive and dangerous, while encouraging the Indians to fight among themselves was both inhumane and unrealistic. Tribes defeated in such wars might seek aid and protection, forcing the British to pick sides. Moreover, he realized that all traders living in the wilderness, whether there illegally or not, would offer tempting targets for plunder if the Indians were encouraged to fight each other. Clearly, however, the military and Indian Departments were operating from the same basic assumption. The Indians were considered to be inherently savage and warlike. It was only a question of how that savagery was to be diverted away from the British. Clothed as it was with the rhetoric of financial retrenchment and yet expressing apparent humanity, Amherst's line of reasoning was readily accepted by London.

Amherst's myopic, but understandable, approach to the West (which formed but a small part of his command responsibilities) was that it continued to be a thinly held and precarious possession between 1760 and 1763. Assuming that the Indians could not be trusted under the safest of circumstances, he refused to resort to 'bribery' (in the form of gift-giving), to curtail occupation of important military sites, or to relax trade regulations. Such actions would be both inexpedient and ineffective, and would be seen by the Indians as a sign of weakness. Fear, instilled by a sufficient display of British military force, would keep the nations in check. If they dared rebel, he promised a dose of what the upstart Cherokee to the south had just received in their abortive war. Amherst promised to 'extirpate them root and branch.' 40

Throughout the winter and spring of 1762-63, rumours were circulating among the Indians that 'we mean to make slaves of them by taking so many forts in their country and that they had better attempt something now to recover their liberty than wait until we are better established'. ${ }^{41}$ Amherst did not think the Indians have it in their power to execute anything serious against us while we continue to be on our guard'. Yet they must be made aware of the 'contemptible figure they make in our eyes' by their constant threats. On the virtual eve of the Indian assault in May, Amherst continued to express surprise that the tribes were so 'misguided' in their antagonism, even after they had 'so often experienced our bounty. ${ }^{\prime 42}$

It was not until he received first-hand reports from his western com- 
manders that Amherst would accept the enormity of the Indian onslaught. He was stunned. As noted by Peckham, the General's 'rage and inhumanity increased as each Indian victory or depredation emphasized his seeming helplessness'.43 When he was warned that a too strenuous counter-stroke might drive the Indians to refuges across the Mississippi, Amherst welcomed the prospect: 'they being more nearly allied to the Brute than to Human creations,' he hoped to be rid of them all. Major Gladwin was advised that all prisoners taken should be executed, while at Fort Pitt he inquired of Colonel Henry Bouquet:

could it not be contrived to send the small pox among these disaffected tribes of Indians? We must, on this occasion, use every strategem in our power to reduce them. ${ }^{44}$

Bouquet agreed with the general concept, and lamented that Amherst's proposal to use European hunting dogs to 'extirpate or remove that vermine' was impractical. By the time of his return to England in late 1763, whatever reputation Amherst had gained in conventional warfare against the French had been seriously compromised in the North American wilderness.

Whether or not Amherst is seen as having 'achieved the greatest military reputation in the British army since the death of Marlborough, ${ }^{\prime 45}$ historians generally are agreed that he was thorough, competent and a stickler for detailed planning. Even his critics, frustrated by his painstaking deliberateness, credit him for 'matching prudence with deliberate action' and for his great skill in the 'conception and execution' of his campaigns. ${ }^{46}$ With Pitt personally directing the strategy and even minute details of the war in America (to the point where Steele suggests that the post of commander-in-chief was virtually redundant), ${ }^{47}$ Amherst was considered 'more sure-footed' than the 'dashing, inventive' and impetuous Wolfe. ${ }^{48}$ In sum, the General was 'essentially a safe man, taking few risks and safeguarding himself against all eventualities. ${ }^{\prime 49}$

As quartermaster for the Duke of Cumberland in Germany prior to his North American appointment, Amherst was noted for his 'scrupulous accounting' and his 'conscientious zeal' in driving bargains for the acquisition of supplies. ${ }^{50} \mathrm{He}$ continued this concern for economy as commander-in-chief, refusing to divide the spoils of war among his officers and insisting that captured materials 'must be converted to the use and good of the public service. ${ }^{51}$ Officers were instructed to keep 'proper receipts ... that no one thing may be embezzled'. When cash was short during the winter of 1758-59, Amherst ordered that neither he nor his officers would receive any pay until the shortage was resolved. It was this 
same emphasis on 'strict' economy which would drive Sir William Johnson and the western Indians to distraction after 1760.

Amherst's inclination to 'wait for certain success' before engaging in offensive action was in full accord with contemporary military theory. ${ }^{52}$ Avoidance of unnecessary battles, detailed preparations, and carefully planned manoeuvers to threaten an opponent's vulnerable supply lines were basic maxims fully appreciated by Amherst. Indeed, the reason for many of his most pronounced delays in launching campaigns was precisely his determination to establish strongly defended rear-areas. During his move against Fort George in 1758, he diverted 2,000 men to guard duty and construction work because 'I could not secure the communication too well to put it entirely out of the power of the enemy to cut any of our stores - one cannot be too secure. ${ }^{53}$

Once his vital lines were secure, his major objective was to threaten those of his enemy. His plan for 1760 proposed to defeat the French army by isolating it from its sources of supply and lines of retreat. With access to reinforcements and aid from France cut by British control of the St. Lawrence at Louisbourg and Quebec City, Amherst had only to isolate the French from their western hinterland as a possible supply or escape route to ensure the destruction of French military power: hence the cumbersome, slow, but doctrinally necessary three-column assault on Montreal in 1760. Whether as allies or opponents, the undisciplined and unreliable Indian warriors were uncomfortable impediments to this strategy.

At first glance the very traits of caution and insight which typified Amherst's successful campaigns against the French seemed to desert him when dealing with the Indians. His actions before 1760 are praised for having successfully penetrated the 'fog of war' through consistently good judgement and perceptive use of contradictory and confusing information. As one writer asserts: 'no commander in British history used the law of probability to greater effect. ${ }^{.55}$ However, by 1763 he is criticized by virtually every writer on the subject for his carelessness, poor planning, or lack of perception. Noting he was 'chiefly distinguished for his absolute self-control' in fighting the French, the same writer claims that 'Amherst proved unfit to deal' with the Indians as he fell victim to his emotions. ${ }^{56}$ The General's only defence for the continental interior, in this scenario, rested on a scattering of weak and isolated garrisons and he presumably 'did nothing to warn the latter to be on the alert. ${ }^{\prime 57}$

Clearly it is neither logical nor probable to assume that Amherst lost his military capabilities in so short a time. The deliberateness, careful planning, and strategic insights which characterized his campaigns before 1760 were still in evidence afterward. The specific program for oc- 
cupying the former French forts in the West, his insistence on maintaining extensive strong points along eastern approaches to the interior, and his persistent, if insensitive, demands for new fortifications as key sites (e.g. Sandusky, Niagara, Crown Point), despite Indians objections, suggests the extent of his defensive preparations: all this at a time when his forces were depleted by illness, garrison duty, and the demands of offensive operations against the French and Spanish New World empires.

The assertion that 'despising the Indians, he under-rated them' is undoubtedly true, as is the charge that he showed 'almost complete ignorance of Indian psychology. ${ }^{\prime 58}$ But to suggest that 'his contempt prevented his taking adequate steps ${ }^{\prime 59}$ either to anticipate or to win an Indian war totally ignores the extensive military preparations which he did make prior to 1763 . The very fact that he probably had both despised and hated his enemy'60 merely underscores his perception of the Indians as inherently warlike, unpredictable, and merciless opponents: traits which made defensive preparations all the more imperative.

Amherst's major short-coming was not that he failed to prepare for an Indian onslaught or that he somehow lost his military insight in 1763. Rather his error was in the assumption that such preparations in themselves would be a sufficient deterrent to any possible Indian attack. In that he was sadly mistaken.

\section{D.R. FARRELL \\ University of Guelph}

Notes

1 Amherst to South Carolina Governor Bull, November 27, 1760, 'Amherst Papers', Public Archives of Canada (microfilm).

2 John Cuthbert Long, Lord Jeffrey Amherst, Soldier of the King (New York: Macmillan, 1933).

3 Amherst to Governor Bull, November 27, 1760, 'Amherst Papers'; Governor Murray of Quebec used virtually the identical expression in referring to the French Canadian population. See Murray, 'Report of the Government of Quebec', June 5, 1762 in Adam Shortt and Arthur G. Doughty, eds., Documents relating to the Constitutional History of Canada, 2nd ed. (Ottawa: Public Archives of Canada, 1918).

4 Amherst to Virginia Governor Fauquier, May 4, 1763, 'Amherst Papers'. 
5 Amherst to Major Henry Gladwin, May 29, 1763, 'Amherst Papers'. For a detailed discussion of the Indian war of 1763 see Howard Peckham, Pontiac and the Indian Uprising (Chicago: University of Chicago Press, 1947); Wilbur R. Jacobs, Diplomacy and Indian gifts; Anglo-French rivalry along the Ohio and Northwest Frontiers, 1748-1763 (Stanford: Stanford University Press, 1950); Francis Parkman, History of the Conspiracy of Pontiac, and the war of the North American tribes against the English Colonies after the conquest of Canada (Boston, 1851); Bernard Knollenberg, Origins of the American Revolution: 1759-1766 (New York: Macmillan, 1960), ch. 8; John W. Shy, Toward Lexington; the role of the British Army in the coming of the American Revolution (Princeton: Princeton University Press, 1965); Lawrence Henry Gipson, The triumphant empire: new responsibilities within the enlarged empire, 1763-1766 (New York: Knopf, 1956).

6 For the view of contemporaries see Johnson to Cadwallader Colden, July 13, 1763, Colden Papers, New York Historical Society Publications (1922), 225; John Porteous to parents, November 20, 1763, Porteous Papers, Burton Historical Collections, Detroit Public Library; George Croghan to General Amherst, April 30, 1763, Michigan Pioneer and Historical Collections, XIX, 183. For the perspective of historians, see Wilbur R. Jacobs, Diplomacy and Dispossessing the American Indians; Indians and whites on the colonial frontier (New York: Scribner, 1972); Peckham; Shy; Parkman; Knollenberg.

7 Long, p. 80.

8 ibid., 38-41, 89, 120; J. Clarence Webster, ed., The Journal of Jeffrey Amherst (Toronto: Ryerson Press, 1931), September 25, 1759, p. 173, October 28, 1759, p. 185.

9 Long, p. 94. Amherst preferred to rely on his own Ranger units under Robert Rogers and his light infantry for scouting and forest fighting.

10 Webster, p. 18.

11 ibid., August 27, 1760, p. 239.

12 ibid., July 17, 1760, p. 219.

13 Long, pp. 96-97.

14 Webster, July 13, 1759, p. 135.

15 Webster, p. 6.

16 ibid., p. 7; see Long, pp. 41-50; Henry Morse Stephens, 'Amherst', Dictionary of National Biography, (London, 1885), I, 351.

17 George F.G. Stanley, New France: the last phase 1744-1760 (Toronto: McClelland and Stewart, 1968), p. 234.

18 Amherst to Governor Boone, July 18, 1762, 'Amherst Papers' Amherst to Johnson; August 9, 1961, Papers of Sir William Johnson (Albany: New York State University, 1921- ), III, 514; Gipson, p. 108; Peckham, pp. 70-71; Shy, p. 110.

19 Amherst to Lord Abermarle, June 4, 1762, 'Amherst Papers'.

20 ibid., see Long, Amherst, p. 153. 
21 Amherst to Governor Hamilton (Pennsylvania), February 26, 1761, 'Amherst Papers'. Amherst to William Pitt, February 27, 1761, ibid.

22 Amherst to Pitt, February 27, 1761, ibid.

23 Amherst to Rutherford, April 10, 1761, 'Amherst Papers'. Long notes that a similar plan was developed for Crown Point, which was also refused in London. Several writers point to Amherst's obsession with fort-building and his concept of strong points as a focus for settlement, see particularly Guy Frégault, La Guerre de la conquête, (Montréal: Fides, 1955), p. 259; Long, p. 177.

24 Cadwallader Colden to Board of Trade, March 1, 1762, New York Colonial Documents, VII, 490; Board of Trade to Albany merchants, June 3, 1762, ibid., 502; Knollenberg, p. 105; Gipson states that these pledges formed a 'solemn pledge'. Lawrence Henry Gipson, Zones of International Friction, (New York: Knopf, 1939-42), pp. 51-52.

25 Amherst to Johnson, February 22, 1761, 'Amherst Papers'.

26 Johnson to Amherst, February 12, 1761, ibid.

27 Amherst to Governor Boone, July 8, 1762, ibid.

28 Amherst to General Monckton, November 13, 1760, ibid.

29 Amherst to Lord Egremont, November 30, 1762, ibid. Detroit was never developed to the extent Amherst intended, although he continued to advocate a major settlement there well after his return to England. See Peter Marshall, Imperial Policy and the Government of Detroit; Projects and Problems, 1760-1774', Journal of Imperial and Commonwealth History (January 1974), 2; 153-89.

30 Amherst to Johnson, February 1, 1761, 'Amherst Papers'; see Amherst to Pitt, February 27, 1761, ibid.

31 Amherst to Governors of New Hampshire, Massachusetts, New York, September 10, 1761, ibid.

32 Amherst to Johnson, February 22, 1761; Amherst to Johnson, April 17, 1761. ibid.

33 Amherst to Johnson, February 22, 1761; Amherst to Johnson, April 17, 1761. ibid.

34 Amherst to Johnson, February 22, 1761, ibid; see Amherst to Johnson, April 17, 1761, ibid; Parkman, p. 147, says this 'zeal for retrenchment' led to 'want, suffering and death' for the Indians; see Amherst to Johnson, April 3, 1763, Johnson Papers, X. 648.

35 Amherst to Governor Bull, November 27, 1760, 'Amherst Papers'.

36 Amherst to Governor Bull, December 12, 1760, ibid.

37 Peckham, p. 88; Johnson to Amherst, December 1761, Johnson Papers, III, 582.

38 Johnson to George Croghan. April 8, 1761. ibid., X, 651.

39 According to South Carolina Governor Johnson, it had 'always been the maxim of our government upon the continent to promote war among the Indians of different nations with whom we trade and are at peace with ourselves for in that 
consists of our safety; being at war with one another prevents their uniting against us', quoted in Harry Ward, 'Unite or die; intercolony relations, 1690-1763, (Post Washington, N.Y.: Kennekat Press, 1971), p. 156.

40 Knollenberg, p. 107.

41 Gladwin to Amherst, April 20, 1763, 'Amherst Papers'.

42 Amherst to Johnson, May 25, 1763, see Long, pp. 183-84.

43 Peckham, p. 226; see also Long, p. 186; Webster, pp. 305, 308.

44 Quoted in C.M. Stotz, 'Defense in the Wilderness' in Prudence Trimble ed., Drums in the Forest (Pittsburgh, 1958), 115; see Peckham, p. 227; Parkman, II, pp. 39-40. Bernhard Knollenberg, 'General Amherst and Germ Warfare', Mississipi Valley Historical Review, XLI (December, 1954), 489-94, 762-63.

45 Sir John William Fortescue, A History of the British Army (London, 1899-1923), II, 408-11; Long, p. vii; Webster, p. 13. Fortescue says he is the greatest Military Administrator' from Marlborough to Wellington.

46 Webster, pp. 12-13; Stanley M. Pargellis, ed., Military Affairs in North America, 1748-1765; selected documents from the Cumberland Papers in Windsor Castle (Hamden: Archon Books, 1969), p. xix, Stanley, p. 334; Frégault, p. 257.

47 Ian Kenneth Steel, Guerillas and Grenadiers; the struggle for Canada, 1689-1760 (Toronto: Ryerson Press, 1969), p. 119.

48 Long, p. 50.

49 Webster, p. 7; for a slightly different emphasis, see Long, p. 75.

50 Long, p. 38. As Long notes, 'the example of Byng was in the mind of everyone', and the necessity of caution was evident.

51 Long, pp. 89, 120.

52 Stephens, $D N B, I, 358$.

53 Long, p. 96; Webster, August 6, 1759, p. 153.

54 Long, p. 177; Frégault refers to him as a 'builder', p. 259; Stephens, DNB, I, 359; Webster, p. 13; Marshall, pp. 185-88.

55 H.C. Rogers, The British Army of the Eighteenth Century (London: Allen and Unwin, 1977), p. 151.

56 Stephens, $D N B, \mathrm{I}, 358$.

57 Webster, p. 20.

58 ibid., 18; see Fortescue, III, pp. 14-15.

59 Stephens, $D N B$, I, 358; see Long, pp. 185f.

60 Stephens, DNB, I, 358; see Webster, pp. 19-20. 